\title{
Rejecting Respectability: On Being Unapologetically Working Class
}

\author{
Sarah Attfield, University of Technology Sydney
}

\begin{abstract}
Many working-class people have aspired to respectability - maintaining cleanliness in the home, presenting an image of 'niceness' through neat modes of dress, or speaking 'proper'. This respectability is intended to show those in power that working-class people are worthy of their attention and assistance. But what happens when workingclass people refuse to be respectable? When they choose to use strong language and won't speak in soft tones? What happens when working-class people do not defer to their 'betters' and instead articulate their anger loudly and assertively? Critiques of class systems and calls for social justice are arguably more threatening when presented in a loud and direct manner. This article considers how the politics of respectability are used against working-class activists.
\end{abstract}

\section{Keywords}

Working class, respectability, representation

The concept of 'respectability' when applied to working-class people is limiting and controlling. According to British sociologist Beverley Skeggs (1997, 1), respectability is not only a significant marker of class due to its influence on how people speak, act and who they associate with, but also because it has been used to create and maintain class systems (Skeggs: 1997, 2). Respectability has been used to classify and divide the working class into those who are and those who are not deserving of assistance and sympathy - classification that has its roots in Enlightenment desires to categorise and order people and things (in order to control them) (Skeggs:1997, 4). According to Skeggs 'respectability was a central mechanism through which the concept of class emerged' $(1997,2)$ and the concept has been enduring. Working-class people (of all ethnicities) have been labelled as 'dangerous, polluting, threatening, revolutionary' (Skeggs: 1997, 1) and therefore needing to be controlled to prevent them from challenging the authority of the ruling classes. The idea of respectability has been central in the attempts to keep working-class people in check.

What then does it mean to be respectable? Respectability involves being polite, speaking in turn, remaining calm and dressing appropriately. Respectability is something that many working-class people have aspired to - manifested in efforts to maintain cleanliness in the home, present an image of 'niceness' through neat modes of dress, to speak 'proper' and avoid coarse language. Respectability should not be confused with respect, which, according to bell hooks is about 'being seen and treated like you matter' (hooks: 2000, 20). Respectability is arguably intended to show those 
in power that working-class people are worthy of their attention and assistance. Working-class people are expected to behave in a respectable way in order to be taken seriously by the dominant classes. But what happens when working-class people refuse to be respectable? When they choose to use strong language and are proud of their working-class accents? What happens when working-class people do not defer to their 'betters' and instead articulate their anger loudly and assertively? I'm suggesting that when working-class people (both ordinary citizens and public figures alike) refuse to act respectfully they can find themselves attacked in the

mainstream media and described as obnoxious or 'mouthy' (loud and brash). ${ }^{13}$ Their ideas can be dismissed and their approach labelled as aggressive. I'm suggesting it's possible that criticism of class systems and calls for social justice are more threatening when presented in a loud and direct manner. This seems to be particularly the case when the calls are being made by working-class women (as I will discuss later).

\section{Autobiography as a research tool}

This article is partly autobiographical and also contains analysis of some media representations of working-class people in the UK and Australia in the context of respectability. ${ }^{14}$ Autobiographical elements are important in the field of new workingclass studies ${ }^{15}$ because the discipline is centred on the lived experiences of class (Linkon and Russo: 2005, 11), and also because many scholars working in the area (such as myself) have working-class backgrounds. Working-class life for me is therefore not abstract, or based on the experiences of 'other' people but is lived, felt and continually influencing. Working-class autobiography has often been dismissed by academics due to a perception that it is overly nostalgic or because the stories of 'ordinary' people have not been valued (Strangleman: 2005, 138). Scholars within the field of working-class studies, such as Strangleman, have found autobiography to be of 'tremendous value' (2005:140) and important as a resource for study into workingclass life and social class. McKenzie (2016) also points to the importance of narrative in working-class communities, and describes storytelling as a method of making sense of the world and of understanding position in a classed society (6). Storytelling has been used in the formation of identity, and for marginalised people is an important way of learning how to exist within a classed, gendered and racialised society (White: 2001, $1)$.

Despite my formal education and my current employment as an academic, I still identify as working class. No longer economically, but culturally. I am different from

\footnotetext{
${ }^{13}$ An example can be seen in the conservative press on British comedian-turned-activist Russell Brand: http://www.dailymail.co.uk/news/article-2859473/PIERS-MORGAN-TV-tantrum-showsrevolutionary-Russell-Brand-really-just-revolting-hypocrite.html.

${ }^{14} \mathrm{My}$ work tends to stretch across continents due to my British background, current residence in Australia, and the connections I have made with American working-class studies colleagues.

${ }^{15} \mathrm{New}$ working-class studies emerged in the mid-1990s in the US initially. Scholars and writers in the field renewed an interest in the study of working-class experience and came together from a wide range of academic disciplines and activist backgrounds. New working-class studies follows on from the work of scholars such as E.P. Thompson (The Making of the English Working Class, 1963), Richard Hoggart (The Uses of Literacy, 1957), Raymond Williams (The Long Revolution, 1961), Tillie Olsen (Silences, 1965), Jonathan Cobb \& Richard Sennett (The Hidden Injuries of Class, 1972) among others. I have not used these classic works in this paper but they form an important backdrop for any scholarly discussion of working-class experience.
} 
my middle-class colleagues. My experiences have not been like theirs and I still do not possess their levels of cultural capital. I relate very strongly to working-class people, not just my family and old friends, but the working-class people I encounter every day. I am angered by the impact of austerity measures and the continuing lack of workingclass representation in political and cultural spheres. I stand in solidarity with my working-class brothers and sisters around the world and acknowledge the ways in which class intersects with race, ethnicity, gender, sexuality, ability and religion. Despite some cultural differences, working-class people world-wide are affected by class structures every day.

\section{Representation}

Media representation is important because it is through representation that workingclass culture is known to those on the outside. Hall argues that representation is one of the 'central practices which produce culture' (1997: 1) and helps to create the shared meanings that constitute a culture (Hall: 1997, 1). Hall states that cultural meanings 'organise and regulate social practices, influence our conduct and consequently have real, practical effects' (1997:3), which is why representation must be analysed and challenged. People outside of the working class are likely to be those with the power to make policy that directly impacts on working-class people. If working-class people are represented negatively and in ways that suggest a lack of 'moral value' (Skeggs: 2005, 48), this not only impacts whether policy makers consider working-class people to be worthy of aid, but such 'symbolic violence' (Skeggs: 1997, 11) can also lead workingclass people to internalise negative representations and attempt to distance themselves from the types of people portrayed as negative. This creates divisions between workingclass people who might otherwise be aligned. But this does not mean that workingclass people are passive and generally accepting of such representations. Working-class people resist negative depictions in what Skeggs refers to as a 'site of class struggle' (2005:49).

The mainstream media frames working-class people in particular ways that impact on how working-class people are perceived, both from inside and outside the working class. Stereotypes are created and used to justify the 'superior positions' of middle and upper-class people and paint pictures of inequality that serve the agendas of those in power (Kendall: 2011,2). Rather than considering or analysing the structural reasons for poverty, the mainstream media focuses on individuals, thereby shifting the blame from oppressive systems of power onto individual working-class people (Kendall: 2011,83 ). Stories of working-class people in the mainstream media tend to present poverty as something that is pathological (Kendall: 2011,86) but also something that can be overcome by individuals (providing they are willing to try). Kendall refers to 'inspirational' stories of working-class people who have managed to lift themselves from poverty as examples of 'exceptionalism framing' that doesn't acknowledge that such stories of class mobility are actually rare (Kendall: 2011, 109- 111). Media framing also reinforces negative stereotypes of working-class people as lacking respectability and therefore undeserving of sympathy due to 'moral irresponsibility' (Webster: 2008, 294). Poor people are portrayed as the 'other' and working-class people encouraged to disassociate themselves from feckless individuals (Kendall: 2011 , 215). Society is therefore absolved of any responsibility. Beider (2015) focuses on the portrayal of white working-class people in the media and suggests that they are often depicted as a "negative rump... an undifferentiated block 
who are welfare-dependant, leading chaotic and dysfunctional lives...' (1). Such treatment does not take into account the diversity of working-class communities reducing people to a homogeneous group makes it easier for them to be dismissed by those in power.

\section{Respectability as Control}

Respectability as a method of controlling working-class people has a long history in Western Europe and North America ${ }^{16}$. The idea of respectability as a virtue embodied by the bourgeoisie became established in the late eighteenth century and has been the subject of study since. According to Duncan and McCoy (2007) respectability was linked to white nationalism and associated with the white bourgeoisie (36). The concept really took hold in the nineteenth century as the white bourgeoisie carved out positions for themselves as superior to the working classes, and based their behaviour on the perceived attributes of the genteel aristocracy (Smith: 2002, 27). Victorian ideas of the working-class as 'socially undesirable' began to take hold and the working-class were portrayed as too fertile, criminal $^{17}$ and lacking restraint (Webster: 2008, 299). Measures of respectability were gendered and used particularly to judge the behaviour of women (Skeggs: 1997, 3). Women were seen as possessing the ability to 'civilise' (through childrearing) and their sexuality, childcare approaches and domestic orderliness was scrutinised (Skeggs: 1997, 47).

In the United States, the epitome of respectability was Benjamin Franklin, who outlined a number of 'virtues' required to be considered respectable (Smith: 2002, 108). These virtues were markers of social standing and were attributes that could be aspired to (Smith: 2002, 204). Franklin listed virtues such as 'temperance', 'frugality', 'chastity', 'cleanliness', and 'moderation', with 'self-indulgence' seen as a lack of virtue (Smith: 2002, 109). Virtues became associated with bourgeois respectability and indicated 'moral competency' (Smith: 2002, 210).

The notions of respectability created by the white bourgeois applied to working-class people of all races, but according to Wolcott (2001), the idea of respectability manifested in specific ways in African American communities (6). In the nineteenth century, respectability was viewed by some African Americans as a way to challenge the negative stereotypes of Black people created by whites. Claiming respectability in relation to cleanliness (of person and home), chastity, and domestic organisation was seen as a way to prove to white people that African Americans were not inferior. Wolcott points to the ways in which some Black female reformers advocated respectability to Black women and positioned themselves as bourgeois and therefore separate from poor and working-class African Americans (2001:6). This notion has been carried into the twenty first century and rhetoric of respectability is still used by some African American community leaders (Wolcott: 2001, 8). Respectability has

\footnotetext{
${ }^{16}$ Respectability has also been used to control people in colonised places - this can be seen in various British colonies such as Australia, where bourgeois respectability was seen as way to distance British settlers from convicts and from the Indigenous population. One way that this manifested was in marriage laws that were intended to make partnerships legal and therefore respectable (and chaste) and to prevent relationships between Indigenous and non-Indigenous Australians (McKenzie: 2003).

${ }^{17}$ The notion of working-class people as criminal precedes the nineteenth century and manifested in Britain as severe punishments (such as hanging) for crimes listed in the Black Acts of the early eighteenth century, which were initially created to punish poachers who were also seen as a political threat (Linebaugh: 2003, 18).
} 
also been used as a survival mechanism for Black women, who have viewed the domestic sphere as one site that can be controlled in a racist society (Wolcott: 2001, 7). hooks (2000: 17) points to the ways in which respect for African American women has often been linked to marriage and perceptions of chastity (20) as well as working hard, both in and outside the home (27). According to scholars like hooks, if respectability can be achieved, then African Americans can consider themselves on the same level as the white bourgeoisie, and therefore superior to the 'white trash' who reject respectability (hooks: 2000, 112). Although hooks (2000) points out that despite a perception that white working-class people might sometimes reject respectability, they do still have 'racial privilege' despite their marginal class status (114).

In the 1990s, both in the UK and US, despite class not being a popular topic for academic discussion (Munt: 2000, 3), the rhetoric of respectability in relation to working-class people was renewed. Public figures and politicians began to refer to 'declining moral standards' and blamed working-class people, particularly single parents and those requiring government assistance (Skeggs: 1997, 50). Those living in 'marginal places' (Shields: 1991, 4) such as council estates started to become targets of attacks and were represented as the epitome of the 'rough' council estate (Watt: 2006, 779). Council estates, which had once been a symbol of equality and dignity for working-class people, were described as places to be avoided, as a 'last resort' (Watt: 2006, 779) for those living there. The implication was that no one would live on an estate by choice and therefore tenants must be too feckless (unemployed, dysfunctional) to find other accommodations, presumably in the private sphere. The rhetoric of dysfunctional working-class people was mainly centered on white working-class people in the UK who, by the 2000s were being labelled as 'chavs' 18 (Hayward \& Yar: 2006, 10). Chavs were portrayed as lacking in respectability due to their behaviour and their appearance - not due to lack of cleanliness or tattiness, but due to their modes of consumption (Webster: 2008, 301). They were mocked for their choices of brands and their perceived conspicuous consumption (Hayward \& Yar: 2006, 18). This treatment put working-class people in a no-win situation. While previous eras (particularly $18^{\text {th }}$ century England) had seen consumption of luxury goods such as sugar (Smith: 2002, 3) used as a way of measuring respectability, chavs were demonised for choosing to buy designer brands (Hayward \& Yar: 2006, 13). With the chav figure stripped of any 'social value' (Tyler: 2011, 536), the systemic causes of poverty and the related dysfunction it causes were not explored; individuals were simply blamed for making bad life choices. The media was awash with stories of dysfunctional chav families, and this classist depiction of working-class people seemed to be appearing uncritically in the mainstream media (Jones: 2011, 2).

\section{The Respectable Family}

When I was growing up, my mother often instructed my brother and me to behave nicely when in public in order to not to 'show her up'. She was very conscious of being judged, and of the need to remain inconspicuous. According to Sayer (2005), this is a common understanding of respectability for working-class people who believe that being 'inoffensive... keeping out of trouble' would prevent them from

\footnotetext{
${ }^{18}$ In the US, the term 'white trash' is an equivalent, and in Australia the term 'bogan' is used in a similar way (as well as 'dole bludger').
} 
becoming the target of upper and middle-class 'moral and aesthetic disapproval' (177). She wanted to prove to people that she was a respectable woman despite living in public housing and needing assistance from social security (welfare). She had come from a 'respectable' working-class family - her father was a bus driver and her mother worked in the bus depot canteen. Her parents owned their own home and they had a car. Her father had been a prisoner of war during WWII, which further added to his respectability. As a young woman my mother had dreamed of travelling, of having adventures. She ended up leaving a respectable job as a local timber merchant company office junior and joined the Women's Royal Air Force. After a few years she tried something else. She worked in a variety of jobs until she met my father and fell pregnant with my brother and then me. We were eventually housed in a new council flat (public housing project) and my mother was able to win back some of her respectability when she started a full time job as a telephonist with the General Post Office. A few years later, my father had left us, and then passed away, and my mother became dependant on government support. She maintained a sense of respectability by keeping our home fastidiously clean and making sure my brother and I were equally scrubbed and tidy. She prided herself on being able to make us nutritious meals on limited resources and staying out of debt (loans sharks circled regularly on our housing estate). She felt she needed to prove that she was a fit mother and able to hold her head high both in the community and beyond. She'd seen children taken from their families and she was always worried that the 'social' would come for an inspection and find a dirty home and take us away.

This striving for respectability was common among working-class people and cut across race, ethnicity and gender lines. On our multi-ethnic council estate there were many well-scrubbed kids of all ethnicities and genders wearing well-ironed shirts and slacks and punished by their parents if caught using bad language. Girls were expected to be ladylike and start their own well cared-for families and boys were expected to become a hard-working breadwinners.

My mother wasn't happy when I strayed from the path of respectability. Although certain aspects of her values had rubbed off - I didn't have the strong Cockney accent of my friends on the estate, and I preferred homemade pies to spam and chips - I rejected respectability in different ways. I became politicised from a very young age (Thatcher was responsible for that) and I started to 'answer back' at school if I thought a teacher wasn't treating us fairly. I started to join political and activist organisations. I stopped looking neat and tidy and started wearing 'alternative' clothes pieced together from charity shop (thrift store) items. I started to draw attention to myself. This challenged the notion that if working-class people worked hard, kept ourselves nice and didn't make a fuss that eventually things would improve. It became clear to me from my early teenage years that middle-class people were not impressed with working-class people (particularly girls) making their opinions known. I had plenty of run-ins with teachers (not due to school work, I was good at that) and made a few enemies. I learnt that making enemies with powerful people can backfire, and I have stories of how standing up for myself meant I missed out on opportunities.

\section{Becoming Middle Class}


As mentioned earlier, despite my formal education and current employment status as an academic, I have never identified as middle class. My political leanings and interest in gender, race, LGBTI issues, social justice and animal rights didn't take me away from my working-class roots. All of my politically minded friends were also workingclass. We didn't mix socially with middle-class people. There was a sense of autodidactism as we read up on Marxism, feminism and racism and attended rallies and left-wing political events (in between shifts in our working-class jobs). Even years later, as a mature-age student in Australia and then a PhD graduate teaching at a university, I held on to my working-class identity.

And I don't want to be middle class. As a working-class academic I can bring a different way of doing things into my work environment. Class-based obstacles, imposter syndrome and the trauma of class straddling aside (Lubrano: 2004, 2), I see my working-class background as an asset to my work in academia. But there are writers and commentators who describe their working-class backgrounds as something they have been fortunate enough to escape from, as something that needs to be escaped (Hitchcock: 2011,21). In an article on the inequalities perpetuated by the private school system in the UK, Guardian journalist Suzanne Moore (2016) acknowledged the impact of class, but her solution was to encourage people to become middle class rather than improving life for working-class people. She was disparaging of some aspects of working-class culture that she considered trashy, such as 'big tellies', and stated that she was 'forever glad I got away' (Moore: 2016, para.11).

Moore refers to journalist Lynsey Hanley's 2016 book Respectable, which charts how Hanley left her working-class background and became middle class. Hanley states that she 'grew up respectable' (in Grant: 2016, para.4), her family lived on a council estate but her father had a respectable, white collar job, and she found the transition from working class to middle class a difficult one due to the 'wall in the head' that initially prevented her from becoming totally middle class (Hanley: 2016, x). This wall included the influence of the council estate and the lingering effects of estate upbringing even after leaving and moving into a middle-class community (Hanley: 2016, x). She refers to council estates as prison-like places that require escape (2008: 5). Hanley claims that working-class people define themselves based on the 'affirmation or repudiation' of respectability (2016:10), and for her, having grown up in a respectable household meant she had respectability on her side, which eventually assisted her passage into the middle class (Hanley: 2016, xi). While she doesn't reject her working-class family, there is a sense that she could only fulfil her ambitions by becoming middle class and taking on middle-class values - these values include 'the act of thinking' (Hanley: 2016, 38), suggesting that intellectual engagement is restricted to the middle and upper classes. I find Hanley's position problematic because it reinforces the perception that being working class is something to overcome. Skeggs (1997) suggests that attempts to 'pass' as middle class and reject working-class identity, leave the class system unchallenged and therefore able to 'reproduce class hierarchies and evaluations which...delegitimate the working class' (91). But I have found that it is possible to maintain a sense of working-class identity while functioning within the university environment, and this opens the space for other working-class academics and students. 


\section{Middle-Class Reactions to Working-Class Activism}

If working-class people reject middle-class respectability, what are the consequences? And what is so intimidating about a working-class activist? Activists from workingclass backgrounds seem to be portrayed as more of a threat than their middle-class counterparts. Is this because they are more likely to be direct? Or more likely to stick to their guns due to firm resolve? Because there is less to lose if you already have nothing? Are working-class activists less self-conscious about speaking out in public, and of how they might be judged? When a working-class activist does gain a public platform, they can face attack from middle-class institutions. There are attempts to bring them down, to 'show them up' (as my mother would say). Their working-class accents and communication styles can be ridiculed. If they are not formally educated, this can be used as an indicator of lack. If they are earning a decent income or working in a middle-class profession (such as academia) this can be used against them, as proof that they have 'sold out' and only have their own interests at heart. They seem to be subject to much more scrutiny than their middle-class activist counterparts.

This was the case when British comedian Russel Brand turned towards social justice activism. Brand has a working-class background and a working-class accent. Since about 2013, Brand has been speaking in public about political issues and using his fame to spread a social justice message, advocating for activist organisations that represent working-class people (such as public housing activists). During this time Brand has been subjected to ridicule from the mainstream middle-class press in the UK for his outspokenness, and many criticisms have focused on his working-class accent, brashness and his lack of formal education rather than the substance of his

comments and ideas ${ }^{19}$. Middle-class commentators appear to close ranks when faced with an activist who doesn't look or sound like them. It's possible that Brand's appeal to working-class fans and his wide reach due to his high profile are threatening to bourgeois notions of respectability. Brand's 'bad' behaviour encourages a rejection of respectability. Respectable bourgeois virtues are eschewed by Brand (very loudly). There also appears to be a level of dissonance for middle-class commentators who find it difficult to reconcile Brand's use of extensive vocabulary and sophisticated language with his working-class accent and use of expletives. The combination of 'vulgar' language and long words is confrontational because it challenges the neat categorisation of working-class people into respectable (intelligent) and not respectable (ignorant). Dismissing Brand as a vulgar comedian is arguably a way to diminish the workingclass causes he has championed.

Working-class academic and activist Dr. Lisa McKenzie has also been on the receiving end of similar treatment. McKenzie often finds that her direct manner, accent and uncompromising attitude are commented upon by middle-class colleagues (McKenzie: 2015, para.3), who are threatened by her working-class identity. In 2015 McKenzie was described by the British mainstream press as both uncouth and a class fraud, and was ridiculed for her opposition to the gentrification of London's East End (Greenwood et al: 2015). McKenzie has centred her research in working-class communities and has been an outspoken advocate for working-class people and a

\footnotetext{
${ }^{19}$ For example, the infamous 2013 BBC interview with Brand presented by Jeremy Paxman, http://www.bbc.com/news/uk-24648651, accessed November 8th, 2016.
} 
fierce critic of middle-class commentators. McKenzie is unapologetic in her workingclassness and refuses to identify as middle class. She recalls the ways in which respectability operated in her working-class childhood, particularly through efforts to keep her family clean, and is acutely aware of the ways that working-class people have been the targets of scorn and mockery (McKenzie: 2015, 3). The combination of her Nottingham accent, tattoos and brightly coloured hair with her sociological training and academic position seems to operate as too much of a contradiction for her middle-class critics, who are threatened by her directness as a working-class academic.

In Australia, class is not often openly discussed (or even acknowledged) in the same way as it is in the UK. But the same threat posed by outspoken working-class people does exist. In May 2016, during an episode of the Australian Broadcasting Corporation's weekly political affairs panel show 'Q\&A', audience member Duncan Storrar asked one of the panelists, a federal government minister, why he wasn't going to benefit from any of the recently announced budget measures ${ }^{20}$. Storrar described himself as disabled, with a 'low education' and working for minimum wage, and explained that lowering the tax-free threshold for someone like him would be extremely significant compared to tax breaks for the rich that they probably wouldn't even notice. Some of the panelists were sympathetic - the federal minister was not but it is what happened after the show that demonstrates how class works. Almost immediately, a concerned individual set up a crowd funding site to raise money for Storrar and his family. Within days, tens of thousands of dollars had been raised, which suggests that the public were sympathetic to his situation ${ }^{21}$. But the rightwing mainstream media immediately started digging dirt, and Storrar was demonised for his former drug addiction and criminal history ${ }^{22}$. Storrar released statements defending himself, touching on his history of mental illness, and a group of community leaders, commentators and organisations wrote an open letter that asked politicians to 'affirm the rights of Australians to participate in public debate without fear of retribution' (Carter: 2016, para 1). There are often 'curly' questions

asked of the panel during Q\&A, but the majority of audience questioners are middle class and 'respectable'. The response from the media reveals how threatening an articulate working-class voice can be. When working-class people breach the centres of power, the establishment will work hard to undermine their credibility (Eltham: 2016) and then label them as undeserving and lacking respectability.

\footnotetext{
${ }^{20}$ Storrar's question can be viewed here: McCauley, Dana (2016) 'Geelong dad Duncan Storrar steals the election debate from the pollies', news.com.au, May $11^{\text {th }}$, http://www.news.com.au/finance/economy/federal-budget/melbourne-dad-duncan-storrar-steals-theelection-debate-from-the-pollies/news-story/3e3bdcd28baf3005b65f677cf3952271, accessed November $8^{\text {th }}, 2016$.

${ }^{21}$ Chang, Charis (2016) 'How Duncan Storrar will spend his \$60,000 GoFundMe money', news.com. $a$, May $27^{\text {th }}$, http://www.news.com.au/entertainment/tv/how-duncan-storrar-will-spend-his60000-gofundme-money/news-story/aaedbf90b0d7fddc7e007f416010d777, accessed November $8^{\text {th }}$, 2016.

${ }^{22}$ Safi, Michael (2016) 'Duncan Storrar went on Q\&A - now his personal life is dragged through the mud', The Guardian, May 13 ${ }^{\text {th }}$, https://www.theguardian.com/media/2016/may/13/duncan-storrarqanda-personal-life-dragged-through-mud, accessed November $8^{\text {th }}, 2016$.
} 


\section{Rejecting Respectability?}

Where then, does this leave working-class activists? Should we learn how to speak like middle-class people? If we do, will we lose the trust of the working-class people we are supposed to be representing? Hearing someone who sounds like you or looks like you in the public sphere is empowering. Seeing someone who is then also speaking truth to power can be transforming. Those in power are aware of this, which is why they try to limit the opportunities for marginalised people to speak back, and when someone slips through the net, they will do their best to try and make them appear unworthy of attention.

Respectability isn't just about being polite (always being polite can be stultifying). It isn't about keeping your front step clean (although I know my mother and many other working-class women were proud of their clean homes). It's about respecting people's rights to be treated equally and to highlight injustice when it occurs - it's about respecting your neighbour's right to not be poor while also respecting their right to spend what little money they have however they like (and to not judge). It's difficult to shake off the effects of primary socialisation but it's important that working-class people who occupy positions of authority, or who have a public platform acknowledge how the politics of respectability work, and firmly reject methods to control workingclass people through judgement and shaming. If the mainstream media are no longer able to divide working-class communities and pit people against each other, then working-class people can find more ways to unite and challenge oppressive class structures.

\section{Author Bio}

Sarah Attfield is a Scholarly Teaching Fellow in the School of Communications at the University of Technology Sydney. Her work is mainly focused on the representation of working class experience in literature and popular culture. She is a regular contributor to the Working-Class Perspectives blog:

https://workingclassstudies.wordpress.com/.

\section{Bibliography}

Beider, Harris (2015) White Working-Class Voices: Multiculturalism, CommunityBuilding and Change, Bristol: Policy Press.

Devine, Fiona, Savage, Mike, Scott, John, Crompton, Rosemary (Eds) (2005) Rethinking Class: Culture, Identities and Lifestyles, Basingstoke: Palgrave Macmillan.

Carter, Lucy (2016) 'Duncan Storrar's treatment by media sparks call to protect right to public debate', $A B C$ News, May 20 , http://www.abc.net.au/news/2016-0520/duncan-storrar-backlash-sparks-debate/7432042, accessed November $8^{\text {th }}, 2016$.

Duncan, Garrett Albert, McCoy, Henrika (2007) 'Black Adolescent Identity and Respectability', The Negro Educational Review, v 58.1-2, pp 35- 48. 
Eltham, Ben (2016) 'The Pursuit Of Duncan Storrar Reveals The Savagery Of Australia's Class Warfare', New Matilda, May $12^{\text {th }}$, https://newmatilda.com/2016/05/12/the-pursuit-of-duncan-storrar-reveals-thesavagery-of-australias-class-warfare/, accessed November $8^{\text {th }}, 2016$.

Grant, Colin (2016) 'Respectable by Lynsey Hanley review - why class difference is an open wound', The Guardian, April $14^{\text {th }}$, https://www.theguardian.com/books/2016/apr/14/respectable-by-lynsey-hanleyreview-class, accessed November $8^{\text {th }}, 2016$.

Greenwood, Chris et al (2015) 'They call us terrorists - but they called Mandela and the Suffragettes terrorists too, insists cereal protester who says she's an 'economic migrant from the Midlands', Daily Mail, September $30^{\text {th }}$, http://www.dailymail.co.uk/news/article-3254302/Academic-ridiculed-likens-cerealprotest-Mandela-Suffragettes-hours-claiming-wasn-t-middleclass.html\#ixzz4PO1OyCEp, accessed November $8^{\text {th }}, 2016$.

Hall, Stuart (Ed) (1997) Representation: Cultural Representations and Signifying Practices, London: Sage.

Hanley, Lynsey (2008) Estates: An Intimate History, London: Granta Publications. (2016) Respectable: The Experience of Class, UK: Allen Lane.

Hayward, Keith, Yar, Majid (2006) 'The 'Chav' Phenomenon: Consumption, Media and the Construction of a New Underclass', Crime, Media, Culture, 2:1, pp 9-28.

Hitchcock, Peter (2011) 'They Must Be Represented? Problems in Theories of Working-Class Representation', PMLA, 115:1, pp 20-32.

hooks, bell (2000) Where we Stand: Class Matters, New York: Routledge.

Jones, Owen (2011) Chavs: The Demonization of the Working Class, London: Verso.

Kendall, Diana (2011) Framing Class: Media Representations of Wealth and Poverty in America, Lanham: Rowman and Littlefield.

Linebaugh, Peter (2003) The London Hanged: Crime and Civil Society in the Eighteenth Century, London: Verso.

Linkon, Sherry, Russo, John (2005) 'Introduction: What's New About Working-Class Studies?' in Linkon, Sherry, Russo, John (Eds) New Working-Class Studies, Ithaca: Cornell University Press, pp 1-18.

Lubrano, Alfred (2004) Limbo: Blue-Collar Roots, White-Collar Dreams, New Jersey: John Wiley \& Sons.

McKenzie, Kirsten (2003) 'Discourses of Scandal: Bourgeois Respectability and the End of Slavery and Transportation at the Cape and New South Wales', Journal of Colonialism and Colonial History, v 4:3, https://muse.jhu.edu/ (accessed November 6, 2016). 
McKenzie, Lisa (2015) Getting By: Estates, Class and Culture in Austerity Britain, Bristol: Policy Press.

(2015) 'Lisa McKenzie: who would be a working-class woman in academia?' The Times Higher Education, October $8^{\text {th }}$, https://www.timeshighereducation.com/blog/lisa-mckenzie-who-would-be-workingclass-woman-academia, accessed November $8^{\text {th }}, 2016$.

Moore, Suzanne (2016) 'Never mind a level playing field - private education is guarded by an electric fence', The Guardian, June $2^{\text {nd }}$, https://www.theguardian.com/commentisfree/2016/jun/01/suzanne-moore-privateeducation-level-playing-field-electric-fence, accessed November $8^{\text {th }}, 2016$.

Morgan, Piers (2014) 'The TV tantrum that shows why 'revolutionary' Russell Brand is really just a revolting hypocrite', Daily Mail, December $4^{\text {th }}$, http://www.dailymail.co.uk/news/article-2859473/PIERS-MORGAN-TV-tantrumshows-revolutionary-Russell-Brand-really-just-revolting-hypocrite.html, accessed November $8^{\text {th }}, 2016$.

Munt, Sally (Ed) (2000) Cultural Studies and the Working Class: Subject to Change, London: Cassell.

Ponsford, Ruth (2011) 'Consumption, Resilience and Respectability Amongst Young Mothers in Bristol', Journal of Youth Studies, v 14.5, pp 541-560.

Sayer, Andrew (2005) The Moral Significance of Class, Cambridge: Cambridge University Press.

Shields, Rob (1991) Places on the Margin: Alternate Geographies of Modernity, London: Routledge.

Skeggs, Beverley (1997) Formations of Class and Gender: Becoming Respectable, London: Sage.

(2004) Class, Self, Culture, London: Routledge.

(2005) 'The Re-Branding of Class: Propertising Culture' in Devine, Fiona, Savage, Mike, Scott, John (Eds) Rethinking Class: Culture, Identities and Lifestyles, Basingstoke: Palgrave Macmillan, pp 46-68.

Smith, Woodruff (2002) Consumption and the Making of Respectability, 1600-1800, New York: Routledge.

Strangleman, Tim (2005) 'Class Memory: Autobiography and the Art of Forgetting' in Linkon, Sherry, Russo, John (Eds) New Working-Class Studies, Ithaca: Cornell University Press.

Tyler, Katharine (2011) ' New Ethnicities and Old Classities: Respectability and Diaspora', Social Identities, v 17.4, pp 523-542. 
Watt, Paul (2006) ' Respectability, Roughness and 'Race': Neighbourhood Place Images and the Making of Working-Class Social Distinctions', International Journal of urban and Regional Research, v 30.4, pp 776-97.

Webster, Colin (2008) 'Marginalised White Ethnicity, Race and Crime', Theoretical Criminology, 12:3, pp $293-312$.

White, Frances, (2001) Dark Continent of Our Bodies: Black Feminism and the Politics of Respectability, Philadelphia: Temple University Press.

Wolcott, Victoria (2001) Remaking Respectability: African American Women in Interwar Detroit, Chapel Hill: University of North Carolina Press. 